\title{
Correlações entre leitura, consciência fonológica e processamento temporal auditivo***
}

\author{
Correlations between reading, phonological awareness and auditory \\ temporal processing
}

Cristina Ferraz Borges Murphy*

Eliane Schochat **

*Fonoaudióloga. Doutoranda em Ciências da Reabilitação pelo Departamento de Fisioterapia, Fonoaudiologia e Terapia Ocupacional da Faculdade de Medicina da Universidade de São Paulo. Endereço para correspondência:

Avenida Padre Antonio José dos Santos, 313 - Apto. 134 - São Paulo SP - CEP 04563-010 (crist78@yahoo.com).

**Fonoaudióloga. Professora LivreDocente do Curso de Fonoaudiologia do Departamento de Fisioterapia

Fonoaudiologia e Terapia Ocupacional da Faculdade de Medicina da

Universidade de São Paulo.

****Trabalho Realizado no Laboratório de Investigação Fonoaudiológica em Processamento Auditivo do Curso de Fonoaudiologia da Faculdade de Medicina da Universidade de São Paulo.

Artigo Original de Pesquisa

Artigo Submetido a Avaliação por Pares

Conflito de Interesse: não

\begin{abstract}
Background: auditory temporal processing and reading. Aim: to analyse the potential correlations between reading acquisition, phonological awareness, and auditory temporal processing in Brazilian children with dyslexia. Method: this study evaluated sixty children, nine to twelve years of age, divided into two groups: a control group of twenty seven children without dyslexia and a study group of thirty three children with dyslexia. The children in both groups were submitted to tests designed to assess reading skills, phonological awareness, and auditory temporal processing. Results: in the results of all three tests, significant differences were found between the dyslexic children and those in the control group, with poorer results for the dyslexic group. However, for both groups, correlations were found only between the performance on the reading test and the performance on the phonological awareness test. Conclusion: dyslexic children demonstrated poorer results in all tests when compared to their controls. However, there was no definitive evidence that their poor performance on the auditory temporal processing tests was directly related to their phonological awareness skills, or even to their reading skills.
\end{abstract}

Key Words: Children; Dyslexia; Hearing.

\section{Resumo}

Tema: influência do processamento auditivo no aprendizado da leitura. Objetivo: analisar a correlação entre leitura, consciência fonológica e processamento temporal auditivo em crianças brasileiras com dislexia. Método: foram avaliadas sessenta crianças de nove a doze anos, sendo trinta e três pertencentes ao grupo com dislexia e trinta e três ao grupo controle. Os testes aplicados envolveram habilidades de leitura, consciência fonológica e processamento auditivo temporal. Resultados: ambos os grupos apresentaram diferenças estatisticamente significantes entre os desempenhos nos testes de leitura, consciência fonológica e processamento auditivo temporal, sendo que o grupo de crianças com dislexia apresentou desempenho estatisticamente pior em todos os testes aplicados. Foi encontrada correlação apenas entre os desempenhos nos testes de leitura e consciência fonológica. Conclusão: Apesar de o grupo de crianças com dislexia ter apresentado pobre desempenho nos testes de processamento auditivo temporal, não é possível afirmar que este esteja relacionado ao pobre desempenho em tarefas envolvendo leitura ou consciência fonológica.

Palavras-Chave: Criança; Dislexia; Audição.

Recebido em 18.07.2008

Revisado em 24.11.2008.

Aceito para Publicação em 03.02.2009.

Referenciar este material como:

- Murphy CFB, Schochat E. Correlations between reading, phonological awareness and auditory temporal processing (original title: Correlações entre leitura,

Z 3 consciência fonológica e processamento temporal auditivo). Pró-Fono Revista de Atualização Científica. 2009 jan-mar;21(1):13-8. 


\section{Introduction}

Nowadays, several theories have been elaborated to find the etiology of dyslexia, a reading disorder. One of the theories is based on a deficit of the temporal processing (1-5). According to Habib (6), difficulties are seen in processing temporal characteristics of different types of sensorial stimuli, as auditory, visual and sensorial-motor stimuli, when presented in a fast manner and in a sequence. More specifically, difficult involving temporal auditory processing would be expressed by a limited ability in processing "short acoustical elements", as consonants that are classified with rapid transition of formants. This would lead, consequently, to a difficulty in associate letters to their specific sounds.

Although several studies show relationship between reading and temporal auditory processing, there are still controversies about this report. Main critics are in respect to the characteristics of behavioral tests, to the type of task administered and to the cognitive demand required to the usage of tasks, including attention and intelligence quotient (IQ) (7-11).

Some questions emerged in relation to the findings of Tallal (1), precursor of this hypothesis. In the research mentioned, although the group of children with dyslexia presented worse results in all comparisons, temporal tests showed a large individual variation. Only some children (45\%) presented more errors than children of the control group with worse results. Bishop et al (7), for example, affirmed that the auditory temporal processing deficit may be presented but it is neither enough nor necessary to cause language disorders.

Considering the questions that are still existent about the relationship of learning to read and auditory temporal processing, the present study aimed to compare the performance of children with dyslexia and a control group in tests involving reading, phonological processing and auditory temporal processing. Moreover, it aimed to investigate a possible correlation between the performances of each test administered.

\section{Methods}

This research was approved by the Ethics Committee for Research Projects Analysis CAPPesq of the Clinical Hospital and of the Medical School of the University of São Paulo (FMUSP), protocol number 649/01, in October the 9th, 2002.

This research was conducted at the Auditory Processing Laboratory of the Speech and Hearing
Sciences Course of the Medical School of the University of São Paulo, from January 2003 to May 2004. Participated in this study 27 children from the control group (15 girls and 12 boys; mean age $=10: 8$ [years ; months]; age range $=9 ; 2-12 ; 4)$ and 33 children from the study group (14 girls and 19 boys; mean age $=10: 5$ [years $;$ months]; age range $=9 ; 5-12 ; 5)$. All children were Brazilian Portuguese native speakers; they all studied in private schools of the same city that guaranteed similar socio-cultural-economic status for the subjects of both groups; they all presented results within the normal range in the basic audiometric evaluation (audiometry, imitanciometry and logoaudiometry). Moreover they could not present cognitive, psychological, neurological or ophthalmological disorders, oral language acquisition delay, otitis media background and they could not have had any previous musical knowledge.

The Brazilian Association of Dyslexia was the responsible for the diagnosis and referral of the studied group. The diagnosis followed these criteria: average or above average intelligence, according to the Intelligence Scale for Children-III (90 or above in verbal and non-verbal tests of intelligence); reading and phonological abilities with two years of delay as compared to the chronological age; anamnesis applied to the caregivers to investigate any other problem that may have influenced reading, as education and teaching method. The control group was constituted of children referred by private schools and the selection was done by teachers that were encouraged to refer children with no scholar complaints.

Individuals of both groups underwent a series of procedures as: clinical history, complete audiometric evaluation composed of meatoscopy, imitanciometry and tonal and vocal audiometry. Following, children that did not accomplish these criteria were excluded from the research and when necessary a referral was done to a specialist. After the groups were constituted, three tests were conducted:

Tests of Single Word Reading / Adaptation (12)

This is a test constituted of 30 words ranging according to regularity (regular and irregular words), to lexicality (real words and pseudowords), to extension (short and long stimuli), to familiarity (frequent and non-frequent words).

Presentation of words was done through an LG computer, using the Microsoft Word program in an acoustically treated room. Stimuli were presented 
one by one on the center of the computer's screen. Duration of each stimulus was unlimited at the beginning and its disappearance was operated by the examiner after the child's answer. Participants were oriented to articulate loudly the stimuli immediately after their appearance on the screen even if they were not sure about the correct answer and if they did not know their meaning, because some of them were pseudowords. Answers were recorded in a Sony TCM -323 recorder for latter transcription. The number of correct answers was computed for each child considering the first answer, that is, self correction was not considered for this analysis.

\section{Phonological Awareness Test (13)}

Test was conducted orally and the subject could not see the lips of the examiner. This test was composed of four tasks: phonemic blending and exclusion, rhyme identification and phonemic segmentation. Each task had three items for practice and five items related to the test. Application of each task was preceded by three initial examples in which the examiner explained what had to be done and, if necessary, the answer was corrected. The number of correct answers was computed for each task.

\section{Auditory Progressive Temporal Test - (14)}

Auditory temporal processing tests are based on a series of tests elaborated by Tallal and Piercy (15), named "Repetition Test". So, the eight tests present differences regarding the type of task (discrimination $\mathrm{x}$ ordering), stimuli and inter-stimuli duration that are named Frequency Ordering Tests (Tests 1 and 2), Duration Ordering Tests (Tests 3 and 4), Frequency Discrimination Tests (Tests 5 and 6) and Duration Discrimination tests (Tests 7 and 8). For more details about the characteristics of each test, readers are referred to Murphy and Schochat (14).

During the conduction of the test, examiner and subject were seated side by side in front of the computer. It was possible to view the program used for the reading of the $\mathrm{CD}$ (track number, seconds remaining and elapsed time) on the screen. Tests were applied in a comfortable intensity that according to the measurement done through a
Sound Pressure Level Measurer, corresponded with approximately $70 \mathrm{dBHL}$. Stimuli were binaural, that is, presented simultaneously in both ears. The type of answer was verbal, so in the ordering tests, participants should say the stimuli order and in the discrimination tests they should say if the stimuli were similar or different.

\section{Results}

Performance comparison of both groups in each test was done using the ANOVA and the significant level considered was .05.

According to the analysis (Table 1), there was significant statistical difference between the mean of correct answers of both groups for the reading tests $(\mathrm{p}<0.001)$, for each phonological awareness test $(\mathrm{p}<0.001)$ and for each auditory temporal processing test $(\mathrm{p}<0.05)$. In all comparison the group of children with dyslexia presented the lower results.

Correlation between performances of the reading, phonological awareness and auditory temporal processing tests were also conducted (Table 2)

In order to facilitate the analysis, results obtained for each of the phonological awareness ability were grouped. As the same manner, the auditory temporal tasks that presented differences according to duration of stimuli were also grouped, that is, Test $1+$ Test 2 , Test $3+$ Test 4 , Tes $5+$ Test 6 and Test $7+$ Test 8 .

Pearson Correlation showed that the group of dyslexic children presented good correlation only between reading and phonological awareness tests $(83.7 \%)$. Correlation between reading and auditory temporal processing ranged between 13 and $26 \%$ (correlation considered very bad to bad) and between phonological awareness and auditory temporal processing tests ranged from 24 to $35 \%$ (considered a bad correlation).

Control group also presented better correlation between reading and phonological awareness tests ( $45.7 \%$, considered a regular correlation). Correlation between reading and auditory temporal processing tests ranged from 0.5 to $31 \%$ (correlation considered very bad to bad) and between phonological awareness tests and auditory processing tests ranged from 12 to $31 \%$ (correlation considered very bad to bad). 
TABLE 1. Performance of the groups in reading, phonological awareness and auditory temporal processing tests.

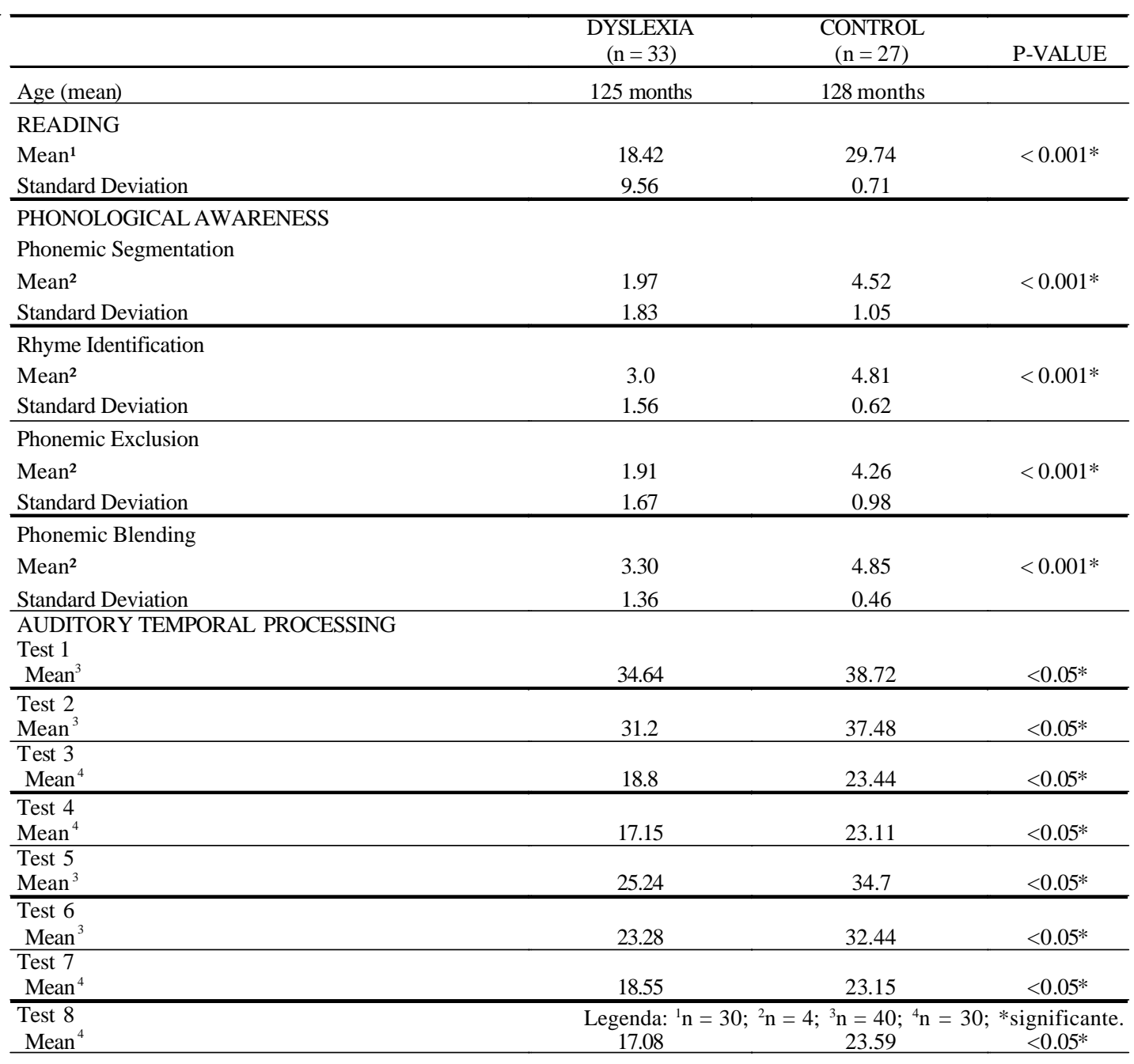

Legend: ${ }^{1} \mathrm{n}=30 ;{ }^{2} \mathrm{n}=4 ;{ }^{3} \mathrm{n}=40 ;{ }^{4} \mathrm{n}=30 ;{ }^{*}$ significant

TABLE 2. Correlation of the performance for the Reading, Phonological Awareness and Auditory temporal processing tests.

\begin{tabular}{|c|c|c|c|c|c|c|c|c|}
\hline \multirow[t]{2}{*}{ Tests } & \multicolumn{2}{|l|}{ Reading } & \multicolumn{2}{|c|}{$\begin{array}{l}\text { Phonological } \\
\text { Awareness } \\
\end{array}$} & \multicolumn{2}{|c|}{ Frequency Disc } & Duration Disc. & Frequency Ord. \\
\hline & dyslexia & control & dyslexia & control & dyslexia & control & dyslexia control & dyslexia control \\
\hline $\begin{array}{l}\text { Phonological } \\
\text { Awareness }\end{array}$ & $83.7 \%$ & $45.7 \%$ & & & & & & \\
\hline Frequency Disc. & $13.8 \%$ & $25.5 \%$ & $29.50 \%$ & $12.50 \%$ & & & & \\
\hline Duration Disc. & $23.3 \%$ & $28.5 \%$ & $24.70 \%$ & $31.10 \%$ & $40.10 \%$ & $18.20 \%$ & & \\
\hline Frequency Ord. & $18.4 \%$ & $0.5 \%$ & $30.30 \%$ & $17.50 \%$ & $24.60 \%$ & $30.10 \%$ & $23.10 \%$ & \\
\hline Duration Ord. & $26.6 \%$ & $31.3 \%$ & $35.60 \%$ & $16.30 \%$ & $14.50 \%$ & $8.30 \%$ & $35.70 \%$ & $12.40 \%$ \\
\hline
\end{tabular}

Legend: Disc=discrimination; Ord=ordering 


\section{Discussion}

The main aim of the present study was to analyze the performance of dyslexic children involving reading, phonological awareness and temporal tasks and investigate a possible correlation between the performances of each test conducted.

Results showed that children with dyslexia presented significant worse results compared to the control group in relation to reading, phonological awareness and auditory temporal processing tasks (table 1 and 2). Regarding the reading test, this result was expected if we consider that the difficulty of reading is the primary complaint of dyslexic children. The performance of the phonological awareness test corroborates a great number of researches that show the importance of the acquisition of phonological abilities for the learning of reading (16-24). Moreover, the good correlation found between the performances of reading and phonological awareness tests of the study group also confirms the high relationship between these variables. According to Temple et al. (25), this is an essential ability for the learning of reading and, at the same time, one of the main complaints of reading and writing disorders. Curiously, and also differently from the study group, the control group presented only regular correlation $(45.7 \%)$. One of the hypotheses for this finding may be due to the difference between the standard deviation of both groups in the reading test. Differently from the study group that seemed to demonstrate subjects with different levels of difficulty in the reading test, all subjects of the control group presented similar performance in this test. This may have raised difficulties in the trace of a correlation between tests as all of them presented the same performance.

Regarding the auditory temporal processing tests, the poor performance obtained by the study group in tasks involving this ability indicates a relationship between reading and auditory temporal processing and also corroborates several studies conducted $(1,3,4,5,26,27)$. However, the correlation found between these two abilities was considered a weak correlation (13 to 26\%) as also for the tests involving phonological processing (24 to $35 \%$ ). Therefore, this result does not show direct relationship between the abilities that were tested (Table 3). One of the hypotheses is that the poor performance of the study group in auditory temporal processing tests may be a consequence of other factors not considered in this research and that in some way could also have influenced the phonological abilities like attention, cognitive abilities and working memory.

Marshal (9) in a similar research also did not find correlation between auditory temporal processing and phonological processing. The author attributed the findings to the level of attention possibly reduced in dyslexic children. In relation to the cognitive abilities and according to research conducted by BenYehudah et al. (10), excellent cognitive abilities of the dyslexic group may interfere in the performance of the auditory temporal processing tests. In the present research all children of the study group underwent a cognitive ability test and no results under the expected range were detected. However, it was not considered the hypothesis that some of the subjects might have presented cognitive abilities above range. This may have lead to a significant difference between the IQ means in each group. Regarding the working memory, Banai and Ahissar (11), for example, analyzed the auditory temporal processing, working memory and reading of a group of dyslexic individuals. The author found that only the subgroup that presented a weak performance in auditory processing tests also presented weak performance in working memory tests. Moreover, the research presented high correlation between tasks involving working memory, cognitive abilities and reading.

The relationship still not explained between reading and language disorders also have influenced the results found. Heath et al (8), for example, verified that only the group that presented concomitant reading and language disorders presented worse results compared to the control group in tests of auditory temporal processing. The group with only reading disorders similar to the one of the present research did not show results differently from the control group. So, it is still discussed if dyslexia and specific language disorders represent, simply, different demonstration of the same underlying disorder (4). Galaburda et al (28) argue that as in great part of the developing deficits, symptoms of the subject with dyslexia may suffer changes during this development (maturation) with some symptoms being modified and others remaining unchanged. This could raise difficulties with the establishment of correlation between symptoms as also the establishment of a causal relationship.

One of the problems discussed by Tallal (1), is the possible existence of subgroups of dyslexic children that may justify the great range of their performance in auditory temporal processing tests. This hypothesis can also justify the absence of correlation found in the present research. Although some criteria were adopted to select the study group in order to constitute a more homogeneous group, the etiology of the problem may not be the same for all children. This could justify the high standard deviation of the study group (Table 1). 


\section{Conclusion}

Concluding, this research indicates that dyslexic children present difficulties in auditory temporal processing tests, but this difficulty was not correlated with the performance in reading and

\section{References}

1. Tallal P. Auditory temporal perception, phonics and reading disabilities in children. Brain Lang. 1980;9:18298.

2. Tallal P, Miller S, Fitch RH. Neurobiological basis of speech: a case for the preeminence of temporal processing. Ann N Y Acad Sci. 1993;682:27-47.

3. Ingelghem MV, Wieringen A, Wouters J, Vendenbussche E, Onghena P, Ghesquiere P. Psychophysical evidence for a general temporal processing deficit in children with dyslexia. Cogn Neurosci Neuropsychol. 2001;12:3603-6.

4. Clark MG, Rosen GD, Tallal P, Fitch RH. Impaired twotone processing at rapid rates in male rats with induced microgyria. Brain Res. 2000;871:94-7.

5. Share D, Jorm AF, MacLean R, Matthews R. Temporal processing and reading disabilities. Reading Writing: Interdisciplinary J. 2002;15:151-78.

6. Habib M. The neurological basis of developmental dyslexia. An overview and working hypothesis. Brain. 2000;123:2373-99.

7. Bishop DV, Carlyon RP, Deeks JM, Bishop SJ. Auditory temporal processing impairment: neither necessary nor sufficient for causing language impairment in children. J Speech Lang Hear Res. 1999;42(6):1295-310.

8. Heath SM, Hogben JH, Clark CD. Auditory temporal processing in disabled readers with and without oral language delay. J Child Psychol Psychiatry. 1999;40(4):637-47.

9. Marshal CM. Auditory and phonological processing in dyslexic and normal readers. 2001 Dphil Thesis: University of York.

10. Ben-Yehudah G, Banai K, Ahissar M. Patterns of defficit in auditory temporal processing among dyslexics adults. Auditory vestibular systems. 2004;15:4-22.

11. Banai K., Ahissar M. Auditory processing deficits in dyslexia: task or stimulus related? Cereb Cortex. 2006;16(12):1718-28.

12. Salles JF. O uso das rotas de leitura fonológica e lexical em escolares: relações com compreensão, tempo de leitura e consciência fonológica. (dissertação). Porto Alegre: Universidade Federal do Rio Grande do Sul; 2001.

13. Fernandes F, Andrade CRF, Befi-Lopes DM, Wertzner HF Manual de avaliação de linguagem do Centro de Saúde Escola Samuel B. Pessoa. Publicação Interna; 1988. 50p.

14. Murphy CFB, Schochat E. Influência de paradigmas temporais em testes de processamento temporal auditivo. Pro-Fono Rev de Atualização Científica. 2007;19(3):25966. phonological awareness tests. Further researches are necessary to better understand each cognitive process involved in reading ability.

15. Tallal P, Piercy M. Developmental aphasia: impaired rate of non-verbal processing as a function of sensory modality. Neuropsychologia. 1973;11:389-98.

16. Fox B, Routh DK. Phonemic analysis and severe reading disability in children. Psycholinguist Res. 1980;9:115-9.

17. Bradley L, Bryant PE. Categorizing sounds and learning to read: a causal connection. Nature. 1983;310:419-21.

18. Wagner RK, Torgesen JK. The nature of phonological processing and its causal role in the acquisition of reading skills. Psychol Bull. 1987;101:192-212.

19. Pratt AC, Brady S. Relation of phonological awareness to reading disability in children and adults. Ed Psychol. 1988;80:319-23.

20. Gathercole SE, Baddlery AD. Phonological memory deficits in language disordered children: is there a causal connection? Mem Lang. 1990;29:336-60.

21. Pennington BF, Van Orden GC, Smith SD, Green PA, Haith MN. Phonological processing skills and deficits in adult dyslexics. Child Dev. 1990;61:1753-78.

22. Goswami U, Bryant P. Phonological skills and learning to read. Hillsdal: Erbaum; 1990.

23. James D, Van Steenbrudgge W, Chiverall K. Underlying deficits in language-disordered children with central auditory processing difficulties. Appli Psycholinguistics. 1994;15:311-28.

24. Mody M, Studdert-Kennedy M, Brady S. Speech perception deficits in poor readers: auditory processing or phonological coding? Exp Child Psychol. 1997;64:199231

25. Temple E, Poldrack R., Salids J, Deutsch G, Tallal P, Merzenich M, Gabrieli J. Disrupted neural responses to phonological and orthografic processing in dyslexic children: an fMRI study. Neuroreport. 2001;12:299-307.

26. Birch HG, Belmont L. Auditory-visual integration in normal and retarded readers. Am Orthopsychiatry. 1964;34:852-61.

27. Talcott JB, Witton C, McLean MF, Hansen PC, Rees A, Green GGR, Stein JF. Dynamic sensory sensitivity and children's word decoding skills. Proc Natl Acad Sci USA. 2000;97:2952-7.

28. Galaburda AM, LoTurco J, Ramus F, Fitch R, Rosen G. From genes to behaviour in developmental dyslexia Nature Neurosci. 2006;9(10):1213-7. 